\title{
REPRESENTASI RONGGENG DALAM TIGA NOVEL INDONESIA
}

\author{
Yulianeta \\ Jurusan Pendidikan Bahasa dan Sastra Indonesia FPBS UPI \\ Korespondensi: Jln. Dr. Setiabudhi No.229 Bandung 40154 \\ Pos-el: nismara@live.com
}

\begin{abstract}
Abstrak
Tulisan ini didasari oleh fenomena bahwa ronggeng merupakan artefak budaya yang sangat populer dalam kehidupan masyarakat, terutama di Jawa. Tradisi ini pada awalnya merupakan bagian dari ritual yang sakral, akhirnya menjadi seni pertunjukan yang cenderung dipandang negatif. Dalam konteks sejarah, ronggeng yang pada konsep awalnya dipandang sebagai budaya sakral pada perkembangannya menjadi budaya profan. Resepsi terhadap ronggeng tidak hanya terlontar secara lisan, tetapi juga tertuang dalam tradisi tulis, yakni di dalam karya sastra yang bergenre prosa fiksi, yakni novel Trilogi Ronggeng Dukuh Paruk karya Ahmad Tohari (2003), Ronggeng karya Dewi Lingga Sari (2007), dan Karti Kledek Ngrajek karya S.W. Warsito (2009). Hasil kajian ini memberikan gambaran bahwa sosok ronggeng yang direpresentasikan dalam ketiga novel tersebut beragam. Meskipun ada kesamaan, tetapi pengarang memiliki tingkat resepsi yang berbeda mengenai ronggeng. Hal itu menggambarkan perkembangan pemikiran masyarakat, ronggeng sebagai artefak kebudayaan daerah merupakan perwujudan dari kemampuan masyarakat setempat dalam menanggapi dan menyesuaikan diri dengan lingkungan secara aktif. Demikian pula apa yang direpresentasikan dalam ketiga novel tersebut tentang ronggeng merupakan cermin dari masyarakat yang melahirkannya.
\end{abstract}

Kata-Kata Kunci: Novel, representasi, resepsi, ronggeng

\begin{abstract}
This paper is based on the phenomenon of dancer or "tayub" which is celebrated as a very popular cultural artifact in public life, particularly in Java. This tradition is originally part of a sacred ritual, which ultimately became a performing art, but tends to be viewed negatively. In a historical context, the dancer was originally seen based on cultural concept and evolves into culturally sacred profane. Negative reception of ronggeng is not only uttered orally but also embodied in the written tradition. It is found in the genre of literary fiction such as in Trilogy Ronggeng Dukuh Paruk written Ahmad Tohari (2003), Ronggeng works Dewi Lingga Sari (2007), and Karti Kledek Ngrajek by S.W. Warsito (2009). The results of this study illustrate that the figure of dancer who is represented in Indonesian fiction are various. Although there are similarities, but the authors tend to have different reception levels regarding "ronggeng". "Ronggeng" as cultural artifacts is the manifestation of the ability of local communities to respond and adapt to the environment actively. Similarly, what is represented in fiction about "ronggeng" is a mirror of the society where the work was born.
\end{abstract}

Key Words: novel, representation, reception, ronggeng 


\section{PENDAHULUAN}

Ronggeng atau tayub adalah salah satu bentuk tari rakyat yang sangat populer. Ronggeng merupakan artefak budaya yang berkembang di seluruh Indonesia. Seni pertunjukan sejenis ini dikenal dengan berbagai sebutan yaitu, tayub, gandrung, lengger, taledhek, tandak dan sebagainya. Ronggeng Melayu berkembang di Sumatra, Ronggeng Betawi berkembang di Jakarta, Bangreng berkembang di Subang dan Sumedang, Jawa Barat. Gandrung dikenal di Banyuwangi, Bali, dan Lombok. Lengger dikenal di Purwokerto, Wonosobo, dan Magelang. Sementara itu sebutan taledhek, ledhek, kledek, joged, ronggeng, serta tandak digunakan untuk menyebut penari perempuan dalam pertunjukan tayub di beberapa daerah di Jawa Tengah dan Jawa Timur, sedangkan di Jawa Barat disebut sindhen atau ronggeng. Bahkan menurut Raffles (1965: 381) dasawarsa kedua abad ke-19 ronggeng terdapat di seluruh daerah Jawa.

Pertunjukan ronggeng atau tayub di Jawa merupakan tradisi yang sudah sangat tua (Soedarsono, 1991; Narawati, 2003; Caturwati, 2008). Istilah tayub sudah dikenal pada masa Jawa Kuna, seperti yang disebutkan dalam buku Old Javanese English Dictionary karya P.J, Zoetmulder dan S.O. Robson (1982) sebagai berikut. Penggalan dari Kakawin Ghatotkacasraya berbunyi “ ... tan hunine watek bini hajin panayub anapuk arja sasmita; penggalan kalimat dari Kidung Wanbang Wideya berbunyi “... aluwaran sri bupati, kuneng rahaden $S$. Malih anayub"; penggalan dari Kakawin Arjuna Pralabda berbunyi “... sang angigel awusan mantuk ndan sang aulun malih anayub prasama linggih mangko" (Zoetmulder dan S.O Robson, 1982). Dalam penggalan kalimat-kalimat di atas, dijelaskan kata anayub atau nayub mirip dengan istilah tayub. Dengan demikian dapat dikatakan istilah tayub sudah muncul pada masa Jawa Kuna abad ke-12, seperti yang disebutkan dalam
Kakawin Ghatotkacasraya maupun Kakawin Bharata Yudha.

Fenomena di atas menunjukkan bahwa ronggeng atau tayub sebagai tradisi sudah mengalami perkembangan karena berbagai adaptasi atau menurut istilah Denys Lombard (2000) silang budaya, baik dengan budaya daerah tertentu, maupun dengan pelaku budayanya. Ronggeng atau tayub di dalam ilmu sastra, khusus sastra lisan (folklor) dapat dikelompokkan sebagai folkor lisan, folklor setengah lisan dan folklor bukan lisan (Brunvand, 1968).

Menurut tradisi lisan kata tayub berasal dari keratabasa atau jarwodosok dari ditata cikben guyub, maksudnya tariannya diatur secara baik agar menjadi kerukunan orang. Etimologi rakyat tersebut tentu saja bertolak belakang dengan makna kata tayub dalam kamus. Misalnya di dalam kamus Baoesastra Djawa kata tayub diberi makna "kasukan jejogedan nganggo dijogedi ing tledek" (Poerwadarminta, 1939:586). Maksudnya bersuka ria menari bersama penari taledhek.

Ronggeng atau tayub merupakan fenomena budaya yang banyak disinggung dalam berbagai tulisan, Serat Centini (1818) karya sastra Jawa terkenal yang berupa tembang dan Babad Mangir Jilid I, serta tulisan-tulisan para pengamat asing yang pernah mengamati kondisi budaya di Indonesia antara lain Thomas Stamford Raffles dalam bukunya The History of Java (1965), Claire Holt dengan karyanya berjudul Art in Indonesia: Continuitis and Change (1967), dan P.J. Zoetmulder dalam bukunya Old Javanese-English Dictionary (1982).

Tulisan-tulisan tersebut pada umumnya sebagian besar memaparkan ronggeng sebagai perempuan penari klangenan yang dikelilingi banyak lakilaki, dipuja, disanjung, atau dijadikan patner tidak saja di arena pertunjukan tari, tetapi juga di atas ranjang. Bahkan Raffles dalam bukunya The History of Java (1965: 381) menyatakan ronggeng tidak ada 
bedanya dengan pelacur yang hanya memikirkan uang dan imbalan yang besar serta perusak rumah tangga orang.

Dari beberapa hasil tulisan di atas terlihat bahwa ronggeng atau tayub pada awalnya merupakan bagian dari tarian dalam upacara keagamaan, berkembang menjadi tarian persembahan pada upacara bedah bumi atau bersih desa, yakni upacara yang berkaitan dengan kesuburan atau persembahan kepada Dewi Sri. Pada tahap berikutnya tayub menjadi tari hiburan yang berkembang di keraton, sebagai bagian tradisi para priyayi. Tayub pun kemudian tumbuh di luar keraton menjadi bagian dari upacara bedah bumi sekaligus tumbuh menjadi hiburan tradisional rakyat di desadesa yang cenderung dipandang negatif karena disertai dengan minuman keras dan tindakan yang tidak senonoh baik dari penari atau ronggeng maupun para penayub. Namun tayub yang cenderung dipandang negatif, saat ini sudah mulai mendapatkan citra yang lebih baik sejak adanya akademisi kesenian dan perhatian pemerintah terhadap kesenian rakyat. Tayub dikemas dalam berbagai bentuk tari dan berkembang di lingkungan yang lebih luas.

Resepsi negatif terhadap seni tayub tidak hanya terlontar secara lisan, tetapi juga tertuang dalam tradisi tulis. Hal ini tampak pula dalam kajian Yulianeta (2013) yang memaparkan bahwa ronggeng atau tayub merupakan artefak budaya yang sangat populer dalam kehidupan masyarakat, terutama di Jawa. Ronggeng yang pada konsep awalnya dipandang sebagai budaya sakral pada perkembangannya menjadi budaya profan. Hal ini juga direpresentasikan dalam prosa fiksi Indonesia. Ronggeng sebagai artefak kebudayaan tiada lain merupakan perwujudan dari kemampuan masyarakat setempat dalam menanggapi dan menyesuaikan diri dengan lingkungan secara aktif.

Selanjutnya dalam tulisan ini secara khusus akan dibahas representasi ronggeng dalam novel Indonesia yakni Trilogi Ronggeng Dukuh Paruk karya Ahmad Tohari (2003), Ronggeng karya Dewi Linggasari (2007), dan Karti Kledek Ngrajek karya S.W. Warsito (2009). Representasi ronggeng dalam ketiga prosa fiksi tersebut menggambarkan perkembangan pemikiran masyarakat tentang tayub atau ronggeng. Karena itu, dalam tulisan ini akan dibahas representasi ronggeng dalam ketiga novel tersenut dengan menggunakan teori sosiologi sastra.

Teori sosiologi sastra sebagai suatu jenis pendekatan terhadap sastra memiliki paradigma dengan asumsi dan implikasi epistemologis yang berbeda daripada yang telah digariskan oleh teori sastra berdasarkan prinsip otonomi sastra. Tulisan -tulisan sosiologi sastra menghasilkan pandangan bahwa karya sastra adalah ekspresi dan bagian dari masyarakat, dan dengan demikian memiliki keterkaitan resiprokal (saling berbalasan) dengan jaringan-jaringan sistem dan nilai dalam masyarakat tersebut (Laurenson dan Swingewood, 1972).

Sosiologi adalah ilmu pengetahuan yang objek studinya berupa aktivitas sosial manusia. Sementara itu, sastra adalah karya seni yang merupakan ekspresi kehidupan manusia. Dengan demikian, meskipun antara karya sastra dengan sosiologi merupakan dua bidang yang berbeda, tetapi keduanya saling berkaitan. Sosiologi tidak hanya menghubungkan manusia dengan lingkungan sosial budayanya, tetapi juga dengan alam. Sastra merupakan suatu refleksi lingkungan budaya dan juga suatu teks dialektika antara pengarang, yaitu situasi sosial yang membentuknya atau merupakan penjelasan suatu sejarah dialektik yang dikembangkan dalam karya sastra (Eagleton, 2002).

Sastra menyajikan gambaran kehidupan, dan kehidupan itu sendiri sebagian besar terdiri dari kenyataan sosial. Dalam pengertian ini, kehidupan mencakup hubungan antarmasyarakat 
dengan orang-orang, antarmanusia, antarperistiwa yang terjadi dalam batin seseorang. Karena itu, memandang karya sastra sebagai penggambaran dunia dan kehidupan manusia, kriteria utama yang dikenakan pada karya sastra adalah "kebenaran" penggambaran, atau yang hendak digambarkan. Akan tetapi, Wellek dan Warren (1990) mengingatkan bahwa karya sastra memang mengekspresikan kehidupan, tetapi keliru kalau dianggap mengekspresikan selengkap-lengkapnya. Hal ini disebabkan fenomena kehidupan sosial yang terdapat dalam karya sastra tersebut terkadang tidak disengaja dituliskan oleh pengarang, atau karena hakikat karya sastra itu sendiri yang tidak pernah langsung mengungkapkan fenomena sosial, tetapi secara tidak langsung yang mungkin pengarangnya sendiri tidak tahu.

Pengarang merupakan anggota yang hidup dan berhubungan dengan orang-orang yang berada di sekitarnya, maka dalam proses penciptaan karya sastra seorang pengarang tidak terlepas dari pengaruh lingkungannya. Oleh karena itu, karya sastra yang lahir di tengah-tengah masyarakat merupakan hasil pengungkapan jiwa pengarang tentang kehidupan, peristiwa, serta pengalaman hidup yang telah dihayatinya. Meskipun demikian, sebuah karya sastra tidak pernah berangkat dari kekosongan sosial. Artinya karya sastra ditulis berdasarkan kehidupan sosial masyarakat tertentu dan menceritakan kebudayaan-kebudayaan yang melatarbelakanginya.

Berangkat dari uraian tersebut, pengertian sosiologi sastra dalam tulisan ini adalah sebagai pendekatan dalam menganalisis karya sastra. Salah satu teori sastra yang dapat dijadikan tolak ukur dalam tulisan ini adalah penerapan analisis sosiologi sastra terhadap ketiga novel yang dikaji, yakni Trilogi Ronggeng Dukuh Paruk karya Ahmad Tohari (1982), Ronggeng karya Dewi Lingga Sari (2007), dan Karti Kledek Ngrajek karya S.W.
Warsito (2009). Ketiga novel tersebut menggambarkan representasi ronggeng dalam prosa fiksi Indonesia. Dari uraian singkat ini, analisis sosiologi sastra berusaha memadukan masa silam dan masa kini, dan berusaha menyusun kembali arti historis tersebut dalam "cakrawala harapan" para pembaca prosa fiksi pada waktu itu. Di samping itu, tulisan ini dapat menyusun kembali pandangan sosial budaya masyarakat Jawa (khususnya) terhadap representasi ronggeng yang hidup dalam batin mereka.

\section{METODE}

Penelitian sebagai kegiatan yang sistematis dan terorganisir memerlukan landasan kerja yang ilmiah, yang meliputi tiga hal. Pertama, landasan teori yaitu landasan yang berupa hasil perenungan terdahulu terkait dengan masalah dalam penelitian dan bertujuan mencari jawaban secara ilmiah. Kedua, landasan metodologis yaitu landasan yang berupa tata aturan kerja dalam penelitan dan bertujuan untuk membuktikan jawaban teoretis yang dihasilkan. Ketiga, landasan kecendikiaan yaitu bekal kemampuan membaca, menganalisis, menginterpretasi, dan menyimpulkan (Chamamah-Soeratno, 2002:14-15).

Metode yang digunakan dalam kajian ini adalah metode yang bersifat deskriptif-kualitatif. Dinyatakan bersifat deskriptif kualitatif karena pelaksanaan penelitian ini menggunakan beberapa konsep dan prinsip metodologis penelitian kualitatif (Bodgan \& Biklen, 1982). Beberapa konsep dan prinsip metodologis yang dimaksud, di antaranya berupa konsep atau asas tentang sumber data, pengumpulan data, dan teknik analisis data. Adapun penggunaan beberapa konsep dan prinsip yang dimaksud disesuaikan dengan keperluan penelitian. Maksudnya konsep tersebut tidak diuraikan tersendiri secara teoretis, tetapi diuraikan secara terpadu dengan masalah representasi ronggeng dalam ketiga novel yang dikaji. 


\section{HASIL DAN PEMBAHASAN}

\section{Representasi Ronggeng dalam Novel Ronggeng Dukuh Paruk, Ronggeng, dan Karti Kledek Ngrajek}

Representasi ronggeng dalam novel

Ronggeng Dukuh Paruk ditampilkan melalui karakter Srintil. Ia sama sekali tidak dideskripsikan sebagai perempuan yang cantik memesona. Srintil dipercayai masyarakat sebagai perempuan yang kemasukan roh indang sehingga dirinya bisa menari sedemikian rupa tanpa adanya yang mengajari. Karakter Srintil dikisahkan erat kaitannya dengan hal yang sakral, seperti tampak dalam kutipan berikut

Di pedukuhan itu ada kepercayaan kuat, seorang ronggeng sejati bukan hasil pengajaran. Bagaimanapun diajari, seorang perawan tak bisa menjadi ronggeng kecuali roh indang telah merasuk tubuhnya. Indang adalah semacam wangsit yang dimuliakan di dunia peronggengan (Tohari, 2003: 8).

Keberadaan roh indang sebagai penentu apakah perawan tersebut bisa menjadi ronggeng atau tidak menunjukkan bahwa profesi seorang ronggeng tersebut erat kaitannya dengan hal yang sakral. Hal yang sakral tersebut dikaitkan dengan adanya kepercayaan masyarakat. Kepercayaan tersebut sama sekali tidak dikaitkan dengan perolehan materi. Selain indang, terdapat aspek sakral lainnya yang akan memperkuat daya magis pesona Srintil. Aspek tersebut di antaranya adalah pemanfaatan guna-guna, pekasih, susuk, dan pengaturan penyerahan Srintil pada dukun ronggeng agar menjadi ronggeng yang laris. Menjadi ronggeng karena adanya indang menunjukkan bahwa peran perempuan sebagai ronggeng bukan terlahir dengan sendirinya, tetapi dibentuk oleh budaya yang ada di masyarakat tersebut. Identitas sebagai ronggeng dibentuk sedemikian rupa agar sesuai dengan keinginan masyarakatnya. Dalam konteks ini, tubuh perempuan tampak dilekatkan dengan berbagai nilai yang "memenjarakannya".

Selain itu, agar layak menjadi ronggeng Srintil harus melakukan upacara bukak klambu. Ritual tersebut merupakan acara pelepasan keperawanan Srintil. Lelaki yang akan mendapatkan keperawanan Srintil harus membayar sejumlah uang yang besarannya ditentukan oleh dukun ronggeng. Keberadaan tradisi demikian menunjukkan bahwa keperawanan perempuan ialah sesuatu yang berharga. Tidak semua lelaki sanggup memenuhi syarat yang ditentukan oleh dukun ronggeng. Lelaki yang sanggup memenuhi syarat tersebut ialah lelaki yang kaya. Hal tersebut mengindikasikan bahwa keperawanan perempuan bisa dibeli dengan uang.

Srintil melakukan perlawanan terhadap tradisi sebagai ronggeng. Srintil menyerahkan keperawanannya pada Rasus, lelaki yang dicintainya. Srintil tidak menceritakan hal tersebut pada siapa pun. Perlawanan Srintil dapat dipandang sebagai pemosisian Srintil sebagai subjek yang memiliki otoritas atas tubuhnya.

Sebagai ronggeng, Srintil dipuja oleh para istri lelaki yang menari dengannya Bahkan para istri akan sangat senang jika Srintil mau melakukan hubungan seksual dengan suaminya. Kecemburuan para istri terhadap ronggeng dalam masyarakat Dukuh Paruk tidak pernah ada. Hal tersebut terjadi karena dalam masyarakat Dukuh Paruk, ronggeng bukan saja berfungsi sebagai sosok yang sakral tetapi juga berfungsi sebagai penentu kejantanan lelaki (dilihat dari birahinya). Berikut adalah kutipannya.

Seorang ronggeng di lingkungan pentas tidak akan menjadi bahan percemburuan bagi perempuan Dukuh Paruk. Malah sebaliknya. Makin lama seorang suami bertayub dengan ronggeng, makin bangga pula istrinya. Perempuan semacam itu puas karena diketahui umum bahwa suaminya seorang lelaki jantan, baik 
dalam arti uangnya maupun birahinya (Tohari, 2003: 33).

Meskipun banyak yang memuja, namun tetap ada pandangan masyarakat yang menganggap ronggeng sama dengan sundal. Masyarakat yang memiliki pandangan demikian salah satunya adalah Rasus. Pandangan demikian dilatarbelakangi oleh intensitas aktivitas seksual yang dilakukan Srintil. Srintil sebagai ronggeng ditampilkan sebagai sosok yang dipuja sekaligus sosok yang dilecehkan.

Keberadaan sosok laki-laki yang dicintai dalam kehidupan ronggeng acap kali digambarkan sebagai sosok pahlawan yaitu sosok yang akan melepaskan ronggeng dari kebiasannya bahkan melepaskan ronggeng tersebut dari profesinya. Dalam novel ini pun, sosok laki-laki diharapkan sebagai pahlawan. Berbeda dengan laki-laki, sosok ronggeng digambarkan sebagai perempuan yang pada akhirnya jenuh menjalani profesinya. Ia akan menginginkan menikah, memiliki anak, dan membangun keluarga. Di akhir cerita, Srintil menjadi gila. Srintil sebagai ronggeng dikisahkan terganggu psikisnya.

Sementara sosok ronggeng dalam novel Ronggeng karya Dewi Linggasari ditampilkan melalui Pursilah, seorang ronggeng yang laris dan memiliki daya pikat luar biasa. Untuk menjadi seorang ronggeng Pursilah harus melakukan berbagai ritual dan mematuhi aturan-aturan dan menjauhi pantangan-pantangan. Pursilah memiliki "guru" seorang perempuan. Pursilah memanggilnya dengan sebutan "Nyai". Karakter Nyai inilah yang kemudian memberi tahu atau mengatur gerak-gerik Pursilah agar Pursilah berhasil menjadi seorang ronggeng. Nyai mengetahui dengan persis bahwa profesi yang dijalani Pursilah sangat rentan terhadap terjadinya pembuahan. Oleh karena itu, Nyai telah mendadah kandungan Pursilah sehingga kemungkinan
Pursilah untuk hamil bagi setiap kunjungan tamunya tidak pernah ada.

Menjadi seorang ronggeng berarti memiliki tubuh yang sangat sensual. Seksualitas tersebut kemudian dimanfaatkan sedemikian rupa sehingga menjadi komoditas. Nyai mengatur sedemikian rupa agar Pursilah tetap memiliki pelanggan yang royal. Posisi Nyai dalam kehidupan Pursilah menempati posisi yang sangat penting. Nyai membuat Pursilah berperilaku sedemikian rupa agar sesuai dengan apa yang diinginkan lelaki.

Pursilah sebagai ronggeng ternama di satu sisi menjadi sosok yang dikagumi karena kecantikan, kemolekan tubuh, dan kepemilikan harta. Akan tetapi pada sisi lain, Pursilah pun menjadi sosok yang ditakuti para istri. Para istri takut jika suaminya direbut oleh Pursilah. Meskipun demikian, persaingan antarperempuan dalam novel ini tidak digambarkan terjadi antara Pursilah dengan perempuan desa. Hal tersebut tidak terjadi karena perempuan desa tersebut memiliki suami yang tidak memiliki kesanggupan materi untuk dapat berhubungan seksual dengan Pursilah.

Persaingan antarperempuan dalam novel ini digambarkan melalui Pursilah yang iri terhadap Sarinah, istri Pambudi. Sarinah dikisahkan sebagai kembang desa yang sangat cantik. Sarinah tidak perlu menjadi ronggeng untuk memperoleh materi dan kasih sayang karena dirinya diperistri oleh Pambudi, lelaki tampan yang bekerja sebagai sinder di perkebunan. Rasa iri Pursilah, mengantarkan Pursilah melakukan berbagai cara agar Pambudi jatuh ke dalam pelukannya.

Pada kisah selanjutnya, Pursilah dideskripsikan sebagai perempuan yang setia pada Pambudi dan akan meninggalkan profesinya sebagai ronggeng jika diperistri oleh Pambudi. Deskripsi demikian menunjukkan adanya isu mengenai kesetiaan yang diusung dalam novel ini, terutama kesetiaan dalam menjaga pernikahan. 
Pernikahan dipersepsi sebagai sesuatu yang harus dijaga oleh suami dan istri. Pambudi sebagai laki-laki yang dikisahkan melakukan perselingkuhan dengan sang ronggeng, dikisahkan mengalami kemunduran dalam melakukan pekerjaan bahkan dideskripsikan mengalami kecelakaan yang merenggut nyawanya karena perselingkuhan tersebut. Sementara itu, Pursilah sebagai ronggeng yang dicap sebagai perempuan sundal yang mengganggu kehidupan pernikahan. Pursilah mengalami nasib tragis karena terpaksa bunuh diri karena mengetahui Pambudi akan membunuhnya.

Nasib tragis juga dialaminya ketika rahimnya dimanipulasi. Pursilah harus menjalani ritual pemijatan untuk menghindari kehamilan. Ritual pemijatan dilakukan agar Pursilah leluasa melaksanakan perannya sebagai ronggeng tanpa adanya hambatan karena dirinya hamil. Kehamilan dipandang sebagai sesuatu yang mengancam atau menghambat karena akan melibatkan perasaan dan menguras energi ronggeng. Selain itu, sang ronggeng tentu akan kebingungan menentukan siapa ayah dari bayi yang dikandungnya karena ronggeng melakukan aktivitas seksual dengan banyak laki-laki.

Dalam novel dikisahkan bahwa ronggeng sering kali ditanggap dalam acara yang berkaitan dengan kesuburan: bersih desa, panen, pernikahan, dan sebagainya. Ronggeng pun dikisahkan merupakan simbol kesuburan karena memiliki daya magis yang sensual. Ronggeng diibaratkan sebagai bumi sedangkan lelaki yang dikenai sampur diibaratkan sebagai langit. Perpaduan keduanya dianggap membawa kesuburan, sebagaimana hujan yang merupakan pembawa kesuburan.

Simbol kesuburan yang dilakukan dalam ritus tampaknya berbanding terbalik dengan kehidupan ronggeng yang dikisahkan dalam novel. Ronggeng justru dibuat sedemikian rupa agar tidak subur, agar tidak hamil. Kehamilan akan menghambat ronggeng dalam memperoleh materi yang melimpah. Deskripsi demikian menunjukkan adanya perbedaan antara ronggeng pada tataran ritual dan praktis (sebagai pemuas hasrat seksual). Selain itu, hal ini pun menunjukkan bahwa telah ada pergeseran mengenai ronggeng yang dahulu dipandang sebagai sesuatu yang sakral, kini dipandang sebagai sesuatu yang profan yang dalam pertunjukannya lebih mengetengahkan sensualitas dan aktivitas seksual semata yang kadarnya diukur dari materi.

Dalam novel Karti Kledek Ngrajek Karya S.W. Warsito Karti merupakan nama karakter perempuan dalam novel ini. Ia sangat ingin menjadi "kledek". Kledek yaitu sebutan bagi ronggeng dalam masyarakat desa Ngrajek. Karti dideskripsikan sebagai perempuan yang sangat cantik dan memiliki daya pikat yang luar biasa. Daya pikat tersebut merupakan modal utama bagi kledek.

Dalam novel ini dikisahkan kehidupan Karti yang kemudian mampu menjadi kledek. Perjalanan hidup Karti tersebut merepresentasikan kehidupan ronggeng. Untuk menjadi seorang kledek, Karti harus memiliki daya tarik dan kelebihan tersendiri. Daya tarik tersebut terletak pada wajah, tubuh, dan seksualitas yang dimiliki Karti. Dengan demikian, Karti memiliki kelebihan jika dibandingkan dengan ibu-ibu rumah tangga secara umum atau perempuan desa pada umumnya. Pengarang berupaya menunjukkan perbedaan yang sangat jauh antara Karti dengan perempuan desa pada umumnya. Hal itu terletak pada daya pikat yang kuat.

Karti yang sejak kecil memang memiliki kecantikan dan tubuh yang indah dianggap memiliki daya pikat yang kuat sehingga banyak yang meramalkan Karti akan menjadi kledek yang laris. Meskipun demikian, Karti harus mengasah daya pikat tersebut agar dirinya dapat menjadi kledek yang laris. Seorang kledek yang laris 
memiliki materi yang berlimpah. Menjadi kledek berarti sama pula dengan mendapatkan peluang memperoleh kehidupan yang lebih baik dan memiliki lebih banyak pilihan dalam hidupnya. Kebebasan yang dimiliki Karti dalam menentukan hidupnya diberikan karena ada harga yang harus dibayar. Ia harus menjadi perempuan ideal dalam benak laki-laki masyarakat desa tersebut. Agar cantik dan menjadi kledek terkenal, Karti harus menghafal berbagai mantra dan melakukan berbagai ritual. Ia pun harus patuh pada apa yang harus dilakukan dan pantangan yang tidak boleh dilakukan. Dalam menjalankan ritual tersebut, Karti dibimbing oleh seorang guru. Guru tersebut ialah laki-laki. Hal menarik dalam novel ini adalah keberadaan seorang guru laki-laki. Guru tersebutlah yang mengajari Karti menari padahal guru tersebut profesinya adalah sebagai tukang kendang dalam pagelaran kledek. Berikut adalah kutipan hal-hal yang harus dilakukan Karti agar dapat menjadi kledek.

Lik Sugimin menjelaskan panjang lebar tentang semua yang harus dilakukan oleh seorang kledek agar laris dan menjadi terkenal, termasuk berbagai mantra dan ritual yang harus ditempuh, serta hal-hal yang harus dilakukan dan pantangan yang tidak boleh dilakukan. Ia menuruti semua yang dikatakan Lik Sugimin. (Warsito, 2009: 74)

Pada kutipan di atas, tampak bahwa keberadaan Lik Sugimin berperan penting dalam pengorbitan Karti sebagai kledek. Dalam konteks ini, pengarang tampak menunjukkan bahwa kecantikan perempuan atau persepsi laki-laki terhadap perempuan sangat menentukan apakah perempuan tersebut mampu menjadi apa yang diinginkannya. Hal tersebut menunjukkan bahwa kecantikan perempuan itu tidak pernah lepas dari konteks sosial dan budaya. Kecantikan perempuan itu dikonstruksi sedemikian rupa agar sesuai dengan apa yang diinginkan laki-laki.

Karti kemudian menjelma menjadi kledek yang memiliki daya pikat kuat dideskripsikan memiliki kekuasaan. Ia berkuasa untuk menentukan lelaki mana yang akan dimasuki kehidupannya. Kekuasaan Karti sebagai kledek sangat ditentukan oleh daya pikatnya yang luar biasa. Daya pikat seksual tersebut dapat dipandang sebagai kekuatan yang dimiliki perempuan. Dalam konteks cerita ini, Karti dapat memanfaatkan tubuhnya untuk memperoleh apa yang diinginkannya. Oleh sebab itu, dalam novel ini karakter Karti digambarkan sebagai objek fetish, yaitu objek yang dipuja sekaligus dilecehkan karena dianggap memiliki kekuatan, rangsangan, dan hasrat tertentu.

Dengan kemampuannya sebagai kledek, Karti mampu bangkit dari kemiskinan. Meskipun kecukupan materi telah membuat status sosial Karti meningkat, ia mengalami kekosongan dalam jiwanya. Kekosongan jiwanya tersebut disebabkan oleh perbuatan orang tuanya yang dianggapnya tega menyerahkan keperawanannya pada Lik Sugimin. Karti diceritakan tidak pernah melakukan hubungan seksual atas dasar cinta. Hubungan seksual itu dilakukan semata-mata untuk mendapatkan materi karena Karti 'mati rasa'. Berdasarkan deskripsi tersebut, tampak bahwa pengarang ingin menunjukkan isu keperawanan merupakan hal yang penting.

Rasa bersalah karena dirinya tidak perawan dan menjalani profesi sebagai kledek yang telah berhubungan seksual dengan sejumlah lelaki, membuat Karti merasa bersyukur ada lelaki yang mau menikah dengannya. Karti menyebut Pranowo sebagai lelaki yang "menyelamatkan dan mengentasnya dari lembah hitam yang penuh lumpur" (Warsito, 2009: 166). Pernyataan Karti tersebut memang bertolak belakang karakter Karti yang digambarkan sejak 
kecil bermimpi dan bercita-cita menjadi kledek.

Deskripsi demikian, menunjukkan bahwa Karti mengalami inferioritas diri. Sebagai perempuan yang "tampak superior" karena memiliki banyak harta di mata perempuan dan masyarakat ternyata ia memiliki persepsi negatif terhadap diri dan profesi yang dicita-citakannya tersebut. Ia pun mendambakan pernikahan untuk sebagai bentuk perlawanan dirinya terhadap profesi yang dijalaninya.

\section{Pandangan Pengarang Berkaitan dengan Konteks Sosial, Budaya, dan Tradisi Ronggeng}

Karya sastra tidak lahir dari kekosongan budaya. Oleh sebab itu, karya sastra dapat dilihat sebagai dokumen sosiobudaya yang mencatat kenyataan suatu masyarakat pada suatu masa tertentu. Dokumen sosio-budaya tersebut tentu tidak lepas dari pandangan pengarangnya mengenai kehidupan atau lingkungan di mana ia melahirkan karya sastra. Pandangan pengarang yang berkaitan dengan konteks sosial, budaya, dan tradisi dapat dilihat dari bagaimana pengarang menggunakan sudut pandang dalam mengungkapkan cerita.

Dalam novel Karti Kledek Ngrajek, pengarang menggunakan sudut pandang orang ketiga untuk mengungkapkan cerita. Penggunaan sudut pandang orang ketiga memberikan kesan objektif. Hal ini terjadi karena narator menciptakan jarak antara dirinya dengan karakter yang dikisahkannya. Dengan menggunakan sudut pandang orang ketiga, narator membangun kesan bahwa dirinya hanya melaporkan saja peristiwa-peristiwa yang dialami karakter dalam ceritanya. Pengarang berusaha menunjukkan pada pembaca bahwa kisah yang ditulisnya merupakan kisah 'nyata', kisah yang ditulis secara objektif. Pembaca tentu mengetahui hal ini karena dalam kata pengantar yang ditulis oleh pengarang, dicantumkan hal berikut:
Novel yang ditulis berdasarkan kehidupan nyata, melalui tulisan panjang yang rumit dan tidak mudah memperoleh pengakuan sejujurnya, akhirnya berhasil menguak apa yang sebenarnya terjadi dalam kehidupan seorang kledek, meskipun nama para tokohnya hanya rekaan penulis belaka. (Warsito, 2009: v)

Pengarang berusaha sedemikian
rupa sehingga pembaca diharapkan "memercayai" kisah yang ditulis pengarang adalah fakta, kebenaran yang mutlak mengenai kehidupan kledek. Pengarang pun berusaha menggiring pembaca agar mempercayai bahwa fiksionalitas dalam novel ini hanya terletak pada sistem penamaan karakter.

Selain itu, pada halaman 56 s.d. 65 terdapat syair berbahasa Jawa (gending) dan makna syair yang dibawakan oleh kledek. Deskripsi demikian menegaskan pengarang berusaha menunjukkan bahwa yang ditulisnya tersebut adalah fakta. Dalam novel ini pun terdapat foto-foto yang merupakan dokumentasi Humas Pemda Nganjuk mengenai prosesi yang dijalani kledek. Foto-foto tersebut terpampang jelas dari halaman 210 s.d. 212. Oleh sebab itu, penggunaan sudut pandang orang ketiga sangat efektif mendukung usaha pengarang untuk meyakinkan pembaca bahwa kisah yang ditulisnya ini adalah kisah nyata.

Sama halnya dengan novel Karti Kledek Ngrajek, pengarang novel Ronggeng pun menggunakan sudut pandang orang ketiga sebagai pencerita. Perbedaannya, pengarang novel Ronggeng tidak mengungkapkan secara eksplisit bahwa kisah yang ditulisnya adalah kisah nyata seperti yang dilakukan oleh pengarang novel Karti Kledek Ngrajek. Meskipun demikian, penggunakan sudut pandang orang ketiga sangat ampuh dalam menunjukkan objektivitas kisah yang ditulisnya.

Berbeda dengan pengarang novel Karti Kledek Ngrajek dan Ronggeng, 
pengarang Ronggeng Dukuh Paruk menggunakan sudut pandang orang kedua dan ketiga. Orang kedua tersebut ialah Rasus. Penggunaan sudut pandang ini pun sama efisiennya untuk menunjukkan kesan objektivitas kisah pada pembaca.

Selain memanfaatkan sudut pandang sebagai fokalisasi dalam cerita, pengarang pun tampak memanfaatkan alur untuk menunjukkan objektivitas kisah. Alur yang digunakan dalam ketiga novel tersebut adalah alur linier. Di dalamnya disusun secara sistematis setiap peristiwa secara kronologis. Novel Karti Kledek Ngrajek dan Ronggeng Dukuh Paruk diawali dengan kisah sang ronggeng semasa kecil, cita-citanya menjadi ronggeng, prosesi dan ritual yang harus dijalani agar menjadi ronggeng yang laris kemudian menjadi ronggeng yang laris, dan seterusnya. Sementara itu, kisah dalam Ronggeng diawali dari pertemuan Pursilah dan Pambudi dalam acara pernikahan Pambudi dengan Sarinah. Pursilah jatuh cinta, kemudian menjadi selingkuhan Pambudi, dan seterusnya. Penggunaan alur linier efektif untuk menunjukkan objektivitas cerita.

Melalui sudut pandang demikian, pengarang menghadirkan pada pembaca mengenai pandangannya yang berkaitan dengan konteks sosial kehidupan ronggeng. Dalam Karti Kledek Ngrajek, Ronggeng, dan Ronggeng Dukuh Paruk, sosok ronggeng dihadirkan berasal dari masyarakat kelas bawah. Karti dikisahkan sebagai perempuan miskin yang terpukau pada kehidupan ronggeng yang gemerlap. Pursilah dikisahkan sebagai perempuan miskin yang kehidupan perekonomiannya berubah total setelah menjadi ronggeng. Srintil yang kehidupannya sangat miskin berubah menjadi dapat memenuhi kebutuhannya setelah menjadi ronggeng.

Para ronggeng tersebut lahir dari masyarakat desa yang miskin. Kemiskinan begitu mendera sehingga mereka pun tidak dapat mengenyam pendidikan yang tinggi. Karti dinarasikan hanya lulusan SD.
Pursilah tidak dikisahkan sempat mengenyam pendidikan atau tidak. Kemudian Srintil tidak dikisahkan mengenyam pendidikan. Karena tidak dapat mengakses pendidikan yang tinggi, para perempuan tersebut tidak memiliki nilai tawar lebih terhadap kemampuan yang dimilikinya. Keterbatasan tersebut berbanding terbalik dengan kecantikan yang mereka miliki. Oleh sebab itu, kecantikan dan kemolekan tubuh merupakan modal mereka untuk memperoleh kehidupan yang lebih baik.

Setelah menjadi ronggeng, ketiga perempuan dalam masing-masing novel dikisahkan menjadi perempuan yang mampu memenuhi kebutuhan hidupnya dalam hal materi. Mereka pun dikisahkan memiliki kekuasaan yang sebelumnya tidak mereka miliki. Tampak bahwa pengarang beranggapan seorang perempuan yang berasal dari kelas bawah mampu meningkatkan status sosialnya jika menjadi ronggeng. Modal yang dimiliki oleh Karti dan Pursilah ialah kecantikan, kemolekan tubuh, dan daya pikat yang kuat, sedangkan Ahmad Tohari menunjukkan bahwa modal yang dimiliki ronggeng adalah adanya kekuatan gaib yang memilihnya, yaitu harus dihinggapi roh indang.

Selain itu, pengarang pun mendeskripsikan adanya proses inisiasi. Dalam proses inisiasi inilah pengarang memunculkan pandangannya bahwa ronggeng berakar pada sesuatu yang sakral. Pengarang menunjukkan bahwa ronggeng merupakan hal yang penting dalam kehidupan masyarakat desa yang digambarkannya karena mengandung dokumentasi budaya dan tradisi masyarakatnya. Deskripsi demikian, terlihat jelas dalam novel Ronggeng Dukuh Paruk dan Karti Kledek Ngrajek. Dalam novel Ronggeng Dukuh Paruk, dikisahkan bahwa ronggeng berkaitan erat dengan kiblat kehidupan kebatinan masyarakat Dukuh Paruk yang berkaitan dengan Ki Secamenggala. Tari ronggeng merupakan 
tarian persembahan pada upacara bedah bumi atau bersih desa yang dipersembahkan pada Ki Secamenggala sebagai sosok yang diyakini sebagai pelindung desa. Dalam novel Karti Kledek Ngrajek pun sosok kledek erat kaitannya dengan upacara bedah bumi. Sosok kledek digambarkan sebagai simbol kesuburan. Sementara itu, dalam novel Ronggeng, dikisahkan bahwa konon sosok ronggeng dalam sebuah pertunjukan selalu diibaratkan sebagai ibu pertiwi, adapun laki-laki yang kejatuhan sampur merupakan perlambang hamparan langit. Pertemuan antara langit dan bumi sebagai ibu pertiwi berakibat pada kesuburan yang menimbulkan kemungkinan untuk meneruskan keturunan bagi umat manusia.

Hal itu menunjukkan bagaimana ronggeng merupakan figur kosmis, yang dihubungkan dengan alam transenden melalui roh indang, karena itu memiliki fungsi ritual. Fungsi demikian tampak dalam wisuda Srintil sebagai ronggeng di tanah pekuburan di depan makam $\mathrm{Ki}$ Secamenggala, yang dalam tatanan budaya desa tani sebagai bedah bumi untuk menghadirkan kemakmuran. Hubungan demikian pada tari ronggeng secara magis simpatetis bisa mempengaruhi kesuburan tanah. Namun, akhirnya ronggeng yang berfungsi ritual mengarah ke pertunjukan sekuler. Sebagaimana yang ditunjukkan Ahmad Tohari tentang bagaimana syarat terakhir untuk menjadi ronggeng, yakni harus melalui upacara bukak klambu dan setelahnya ronggeng menjadi milik umum.

Dalam masyarakat tani Jawa, upacara budaya suci memang bersifat fungsional terhadap proses kehidupan. Saat panen pelbagai perayaan diselenggarakan perayaan diselenggarakan dan ronggeng melayani permintaan masyarakat. Dalam upacara demikian gerak tari, tokoh taledhek atau ronggeng, dan minuman keras yang memabukkan oleh Gertz (1976: 299) dianggap sebagai bagian dari tradisi budaya kaum abangan.
Ronggeng atau tayub merupakan ritual untuk persembahan demi kesuburan yang diyakini memiliki kekuatan magisimpatetis. Melalui upacara bersih desa, aparat desa mengajak warganya untuk melakukan tarian di sawah-sawah dengan harapan tanaman menjadi subur dan terhindar dari hama dan mara bahaya. Mengenai upacara kesuburan Highwater (1992:34) dalam tulisannya yang berjudul Dance: Ritual of Experience mengungkapkan bahwa tarian dapat menjadikan adanya keajaiban.

Pendapat tersebut ditegaskan kembali oleh Soedarsono (1991: 35) bahwa dalam budaya masayarakat agraris kesuburan tanah merupakan satu-satunya harapan yang selalu didambakan oleh para petani. Mereka beranggapan bahwa kesuburan tanah juga perkawinan tidak hanya cukup dicapai lewat peningkatan sistem penanaman baru, tetapi juga perlu diupayakan lewat kekuatan yang tak kasat mata. Lebih lanjut Surur (2003:12) menyatakan acara ronggeng menjadi pusat kekuatan penduduk desa seperti halnya slametan, hajatan, atau bahkan sembahayang tahajud bagi kaum santri. Oleh karena itu, upacara kesuburan masih banyak digunakan masyarakat tertentu hingga kini. Hal ini menandakan pemujaan terhadap dewi padi, Dewi Sri di tanah Jawa (Lombard, 2000: 82).

Karena berasal dari sesuatu yang sakral, maka pengarang pun membedakan antara ronggeng dengan perempuan pada umumnya. Ronggeng dideskripsikan bukan saja indah secara fisik sebagai perempuan yang cantik, bertubuh indah, dan memiliki daya pikat yang kuat, tetapi juga menarik secara kasat mata. Untuk menguatkan daya pikat tersebut, para ronggeng harus melakukan ritual tertentu. Pengarang menyebutkan ritual-ritual tersebut untuk menunjukkan bahwa tradisi ronggeng memang berakar pada tradisi daerah tersebut.

Dalam kisah selanjutnya, pengarang menunjukkan bahwa hal sakral 
yang berkaitan dengan ronggeng telah mengalami perubahan. Pengarang menunjukkan bahwa pergelaran ronggeng dalam ketiga novel ini tidak dilakukan di keraton sebagai bagian dari tradisi para priyayi. Para ronggeng dalam ketiga novel tersebut justru lahir dari tradisi masyarakat desa yang jauh dari keraton. Ronggeng dalam ketiga novel justru tumbuh sebagai hiburan tradisional rakyat di desa-desa yang tidak terlalu dikaitkan lagi dengan fungsi sakralnya. Ronggeng cenderung dipandang negatif karena lebih banyak dikisahkan aktivitas seksual yang dilakukan ronggeng. Hal tersebut senada dengan apa yang dikemukakan Raffles (1965: 381) dalam bukunya The History of Java bahwa ronggeng tidak ada bedanya dengan pelacur yang hanya memikirkan uang dan imbalan yang besar serta perusak rumah tangga orang.

Pengarang beranggapan bahwa tradisi ronggeng yang dahulu dianggap sakral kini telah berubah menjadi profan bahkan cenderung dipandang negatif karena berkaitan dengan prostitusi. Karti dalam Karti Kledek Ngrajek dikisahkan sebagai ronggeng yang laris karena sibuk melakukan aktivitas seksual dengan banyak lelaki yang memberinya imbalan limpahan materi. Pursilah dalam Ronggeng pun dikisahkan demikian, sama halnya dengan Srintil dalam Ronggeng Dukuh Paruk.

Selain dipandang negatif karena mengandung unsur prostitusi, profil ronggeng pun disajikan negatif karena ada kecenderungan ronggeng diposisikan sebagai perusak rumah tangga. Ronggeng dikisahkan mau melakukan hubungan seksual dengan siapa saja tanpa pandang bulu apakah lelaki tersebut sudah berumah tangga atau belum. Karti dikisahkan bersedia menjadi istri simpanan bagi banyak lelaki. Sama halnya dengan Karti, Pursilah dikisahkan berusaha menjerat dan merebut Pambudi dari Sarinah, istrinya. Selain itu, di akhir kisah Pursilah ditampilkan sebagai sosok perempuan yang menyebabkan hancurnya rumah tangga Sarinah dan Pambudi.

Dalam ketiga novel yang dikaji ronggeng juga direpresentasikan sebagai perempuan yang tidak subur. Karti, Pursilah, dan Srintil tidak dapat hamil meskipun berhubungan seks dengan banyak lelaki. Hal tersebut terjadi karena rahim mereka telah didedah sehingga tidak dapat dibuahi. Isu mengenai kesuburan ini bertolak belakang dengan citra ronggeng sebagai simbol kesuburan dalam tradisi masyarakat agraris masa lampau. Pemutarbalikan ini menunjukkan bahwa sosok ronggeng kini sudah tidak merepresentasikan kesuburan seperti pada tradisi masa lampau. Kini, tradisi ronggeng telah berubah ke arah yang berkaitan dengan pertukaran materi. Sang ronggeng mendapatkan imbalan sementara lelaki yang berhubungan dengannya harus mengeluarkan imbalan. Jadi, hal sakral tersebut sudah berubah ke arah konsumsi dan transaksi seksual.

Pandangan pengarang terhadap ronggeng dapat dilihat dari bagaimana pengarang memberikan kisah akhir bagi karakter yang diciptakannya. Karti di akhir cerita dikisahkan sangat sedih karena tidak bisa memiliki anak. Ia dikisahkan "taubat" dengan cara naik haji, dan membangun mesjid. Oleh sebab itu, karakter Karti tidak digambarkan terlalu menderita. Deskripsi demikian menegaskan pada pembaca bahwa pengarang menganggap bahwa profesi sebagai kledek sangat dekat dengan maksiat oleh sebab itu, ia menghukum Karti dengan menjadikannya tidak memiliki anak. Pengarang menegaskan bahwa meskipun dosa Karti sangat banyak, ia akan dimaafkan karena bertaubat. Oleh sebab itu, kisah Karti diakhiri pengarang dengan menyebutkan "Selanjutnya nama Karti sudah tenggelam, tidak pernah dibicarakan lagi" (Warsito, 2009: 209).

Dalam novel Ronggeng, Pursilah sebagai ronggeng yang menghancurkan rumah tangga orang lain dikisahkan mati dengan tragis. Pursilah memilih bunuh diri 
karena mengetahui lelaki yang begitu dicintainya, Pambudi berencana membunuhnya. Dengan demikian, dapat dilihat bahwa pengarang tidak menyukai citra ronggeng sebagai orang yang mengganggu kehidupan rumah tangga orang lain. Pengarang "menghukum" Pursilah dengan kematian yang tragis.

Sementara dalam novel Ronggeng Dukuh Paruk, Srintil dikisahkan menjadi gila. Pengarang menunjukkan bahwa menjadi ronggeng tidaklah mudah. Dibutuhkan berbagai pengorbanan meskipun pengorbanan tersebut tidak serta merta membawa kebahagiaan. Tekanan dari berbagai pihak mengenai ronggeng dapat membuat ronggeng tersebut menjadi gila. Selain itu, pengarang pun menunjukkan bahwa untuk memahami ronggeng dibutuhkan "logika tersendiri".

Berdasarkan paparan di atas, dapat disimpulkan bahwa pengarang berusaha menunjukkan bahwa kisah yang ditulisnya merupakan fakta. Hal-hal yang berkaitan dengan tradisi ronggeng pada masa lalu diamini sebagai sesuatu yang pernah ada akan tetapi telah bergeser sedemikian rupa sehingga hal yang dahulu sakral tersebut berubah menjadi profan bahkan sekuler. Pengarang mengamini keberadaan ronggeng sebagai tradisi masyarakat tetapi mereka memilih mengakhiri kisah para ronggeng dengan kejadian menyedihkan bahkan tragis untuk menunjukkan adanya persepsi negatif tentang ronggeng yang memang berkembang di masyarakat.

\section{SIMPULAN}

Berdasarkan uraian di atas, dapat disimpulkan bahwa sosok ronggeng dalam ketiga novel secara fisik dikisahkan sebagai perempuan yang memiliki kelebihan dibandingkan perempuan pada umumnya. Karti, Pursilah, dan Srintil memiliki kecantikan luar biasa, tubuh yang indah, dan daya pikat yang luar biasa kuat.

Keberadaan ronggeng lahir dari sesuatu yang sakral. Meskipun demikian, nyatanya terdapat pergeseran yang amat besar hingga menyebabkan ronggeng yang dahulunya sakral menjadi profan. Ronggeng tidak lagi dikaitkan dengan keilahian tetapi dikaitkan dengan kebirahian. Oleh sebab itu, sosok Karti, Pursilah, dan Srintil ditampilkan begitu banyak menuai pujian sekaligus pula cacian. Pandangan demikian sangat bertalian erat dengan adanya persepsi masyarakat yang memposisikan perempuan sesuai dengan apa yang diinginkan laki-laki. Sementara itu, lakilaki acapkali ditampilkan sebagai pahlawan yang dapat "menggangkat" kehidupan ronggeng dari lembah berlumpur ke kehidupan "normal". Kebutuhan sosok ronggeng terhadap lakilaki yang dicintainya menunjukkan bahwa ronggeng tersebut mengamini anggapan masyarakat bahwa ronggeng ialah liyan.

Pengarang berusaha menunjukkan bahwa kisah yang ditulisnya merupakan fakta. Hal-hal yang berkaitan dengan tradisi ronggeng pada masa lalu diamini sebagai sesuatu yang pernah ada akan tetapi telah bergeser sedemikian rupa sehingga hal yang dahulu sakral tersebut berubah menjadi profan bahkan sekuler. Pengarang mengamini keberadaan ronggeng sebagai tradisi masyarakat tetapi mereka memilih mengakhiri kisah para ronggeng dengan kejadian menyedihkan bahkan tragis untuk menunjukkan adanya persepsi negatif tentang ronggeng yang memang berkembang di masyarakat.

Representasi ronggeng dalam ketiga novel tersebut menggambarkan perkembangan pemikiran masyarakat tentang ronggeng. Ronggeng sebagai artefak kebudayaan daerah merupakan perwujudan dari kemampuan masyarakat setempat dalam menanggapi dan menyesuaikan diri dengan lingkungan secara aktif. Demikian pula apa yang direpresentasikan dalam ketiga novel tersebut tentang ronggeng merupakan cermin dari masyarakat yang melahirkannya. 


\section{UCAPAN TERIMA KASIH}

Penulis mengucapkan terima kasih kepada para kolega di Jurusan Pendidikan Bahasa dan Sastra FPBS UPI yang telah membantu dalam penulisan artikel ini. Ucapan terima kasih juga penulis sampaikan kepada Jurnal Bahasa \& Sastra atas pemuatan artikel penelitian tersebut.

\section{PUSTAKA RUJUKAN}

Bodgan, R. C., \& Biklen, S. 1982. Qualitative Research for Educations: An Introductions to Theory and Methods. Boston: Allyn and Bacon.

Brunvand, Jan Harold. 1968. The Study of American Folklore: An Introduction. New York: W.W. Norton \& Company Inc.

Caturwati, Endang. 2008. Sinden Penari di Atas dan di Luar Panggung. Bandung: Sunan Ambu Press.

Chamamah-Soeratno, Siti dkk. 2002. Metodologi Tulisan Sastra (Ed. Jabrohim) Yogyakarta: Hanindita.

Eagleton Terry. 2002. Marxisme dan Kritik Sastra, Penerbit Sumbu: Yogyakarta.

Geertz, Clifford. 1976. The Religion of Java. Chicago and London: The University of Chicago Press.

Highwater, Jamake. 1992. Dance: Ritual of Experience. Ed 3. New York: The Native Land Foundation.

Holt, Claire. 2000. Melacak Jejak Perkembangan Seni Pertunjukan di Indonesia. Terj. R.M. Soedarsono. Bandung: MSPI.

Linggasari, Dewi. 2007. Ronggeng. Yogyakarta: Kunci Ilmu.
Lombard. Denys. 2000. Nusa Jawa: Silang Budaya. Buku 3. Jakarta: Gramedia.

Laurenson, Diana dan Alan Swingewood. 1972. The Sociology of Literature. London: Granada Publishing Limited.

Narawati, Tati. 2003. Wajah Tari Sunda dari Masa ke Masa. Bandung: Pusat Tulisan dan Pengembangan Pendidikan Seni Tradisional Universitas Pendidikan Indonesia.

Poerwadarminta, W.J.S. 1939. Baoesastra Djawa. Batavia: J.B. Wolters.

Raffles, Thomas Stamford. 1965. The History of Java. Vol 1. London and New York: Oxford Uniersity Press.

Soedarsono, R.M. 1991. "Tayub di Akhir Abad ke-20" dalam Soedarso, Sp., ed. Beberapa Catatan Tentang Perkembangan Kesenian Kita. Yogyakarta: BP ISI.

Surur, Miftahus. 2003. "Perempuan Tayub: Nasibmu di Sana, Nasibmu di Sini" dalam Srintil No. 2.

Tohari, Ahmad. 2003. Ronggeng Dukuh Paruk. Jakarta: Gramedia Pustaka Utama.

Warsito, S.W. 2009. Karti Kledek Ngrajek. Yogyakarta: Jaring Pena.

Wellek, Rene dan Austin Warren. 1990. Teori Kesusastrtaan, terjemahan Melani Budianta. Jakarta: Gramedia

Yulianeta. 2013. "Ronggeng: Cultural Artifact and Its Representation in Indonesian's Fiction". Leksika: Journal of Language, Literature, and Language Teaching. Vol. 7 No. 1 - Februari 2013. Hlm. 40-49.

Zoetmulder, P.J. dan S.O. Robson. 1982. Old Javanese-English Dictionary. 's-Gravenhage: Martinus Nijhoff. 
bahasa \& sastra, Vol. 14, No.1, April 2014 